\title{
Ropivacaine plasma concentrations are similar dur- ing continuous lumbar plexus blockade using the anterior three-in-one and the posterior psoas compartment techniques
}

[Les concentrations plasmatiques de ropivacaine sont similaires pendant le bloc continu du plexus lombaire réalisé par voie antérieure trois-en-un et par voie postérieure de la loge du psoas] Ismail Kaloul MD, * Joanne Guay MD FrCPC, ${ }^{*}$ Christiane Côté RN, ${ }^{*}$ Antoine Halwagi, $†$ France Varin PhD $†$

\begin{abstract}
Purpose: To compare ropivacaine blood concentrations obtained after a continuous lumbar plexus block performed either by the anterior three-in-one femoral (FEM) technique or the posterior (psoas compartment; PSOAS) technique.
\end{abstract}

Methods: As a substudy of a larger clinical trial, 24 patients were randomly allocated to receive a bolus of $30 \mathrm{~mL}$ of ropivacaine $0.5 \%$ plus epinephrine $1: 200,000$ followed by an infusion of ropivacaine $0.2 \%$ at $12 \mathrm{~mL} \cdot \mathrm{hr}^{-1}$ for $48 \mathrm{hr}$ via one of the two continuous lumbar plexus block techniques. Plasma ropivacaine concentrations, up to $48 \mathrm{hr}$, were measured by high performance liquid chromatography.

Results: Mean plasma ropivacaine concentrations were higher in the PSOAS group at 15, 30, and 60 min (two-way analysis of variance, $P<0.000$ I) but areas under the curve were similar for both groups (FEM $452.4 \pm 253.6 \mathrm{mg} \cdot \mathrm{hr}^{-1} \cdot \mathrm{L}^{-1}$, PSOAS $433.4 \pm 99.0$ $\left.\mathrm{mg} \cdot \mathrm{hr} \mathrm{r}^{-1} \cdot \mathrm{L}^{-1}\right)$. Mean maximal plasma concentrations were observed at $48 \mathrm{hr}$ and were comparable for the two techniques (FEM 2630.9 $\pm 1470.3 \mathrm{ng} \cdot \mathrm{L}^{-1}$, PSOAS 2325. I $\pm 604.2 \mathrm{ng} \cdot \mathrm{mL}^{-1}$ ). There was no correlation between blood concentrations at $48 \mathrm{hr}$ and body weight $\left(r^{2}=0.085, P=0.21\right)$. One patient in the FEM group achieved a concentration of $620 \mathrm{I} \mathrm{ng} \cdot \mathrm{mL}^{-1}$ at $48 \mathrm{hr}$.

Conclusions: Although the posterior PSOAS block results in higher early plasma concentrations of local anesthetic than the anterior three-in-one FEM block, both techniques are equivalent with regards to their potential toxicity when a continuous infusion is administered. Local anesthetic accumulation occurs with an infusion of ropivacaine $0.2 \%$ at $12 \mathrm{~mL} \cdot \mathrm{hr}^{-1}$ and can lead to potentially dangerous concentrations at $48 \mathrm{hr}$.

\begin{abstract}
Objectif : Le but de cette étude est de comparer les concentrations d'anesthésiques locaux obtenues après perfusion continue avec un bloc du plexus lombaire par voie postérieure (Groupe PSOAS) à celles du trois-dans-un (Groupe FEM).

Méthode : Vingt-quatre patients ont été divisés au hasard en deux groupes égaux et ont reçu un bolus de $30 \mathrm{~mL}$ de ropivacaïne 0,5\% adrénalinée à l:200 000 suivi d'une perfusion de ropivacaïne 0,2\% à $12 \mathrm{~mL} \cdot \mathrm{h}^{-1}$ pour $48 \mathrm{~h}$ via un cathéter placé selon l'une ou l'autre de ces deux techniques. Les concentrations de ropivacaïne ont été mesurées par chromatographie en phase liquide jusqu'à $48 \mathrm{~h}$.
\end{abstract}

Résultats : Les concentrations moyennes de ropivacaïne sont plus élevées pour le groupe PSOAS à 15, 30 et 60 min (ANOVA, $P<$ 0,0001 ), mais les aires de surface sous la courbe sont similaires pour les deux groupes (Groupe FEM: 452,4 4 253,6, Groupe PSOAS: 433,4 \pm 99,0 $\left.\mathrm{mg} \cdot \mathrm{h}^{-1} \cdot \mathrm{L}^{-1}\right)$. Les concentrations maximales sont mesurées à 48 h et comparables: 2630,9 \pm 1470,3 (Groupe FEM) et $2325,1 \pm 604,2 \mathrm{ng} \cdot \mathrm{mL}^{-1}$ (Groupe PSOAS). II n'y a pas de corrélation entre les concentrations plasmatiques à $48 \mathrm{~h}$ et le poids corporel $\left(r^{2}=0,085, P=0,21\right)$. Un patient du groupe FEM a atteint une concentration de $6201 \mathrm{ng} \cdot \mathrm{mL}^{-1}$.

Conclusion : Bien que l'approche postérieure engendre des concentrations précoces plus élevées, en perfusion continue, les deux techniques sont comparables quant à leur potentiel toxique. Une perfusion de ropivacaïne $0,2 \%$ à $12 \mathrm{~mL} \cdot \mathrm{h}^{-1}$ peut induire des concentrations potentiellement dangereuses si elle est maintenue pour $48 \mathrm{~h}$.

From the Departments of Anesthesiology, ${ }^{*}$ Maisonneuve-Rosemont Hospital; and the Faculty of Pharmacy, $†$ University of Montréal, Montréal, Québec, Canada.

Address correspondence to: Dr. Joanne Guay, Département d'anesthésie-réanimation, Hôpital Maisonneuve-Rosemont, 5415, boul. l'Assomption, Montréal, Québec HIT 2M4, Canada. Phone: 514-252-3426; Fax: 514-252-3542; E-mail: joanne.guay@umontreal.ca This study was funded by a grant from la Fondation d'anesthésiologie du Québec. Dr. France Varin is funded by le Fonds de recherche en santé du Québec and l'Institut de recherche en santé du Canada. Presented at the American Society of Anesthesiologists' Annual Meeting. Orlando, Florida, USA, October 2002.

Accepted for publication March 20, 2003.

Revision accepted May 15, 2003. 


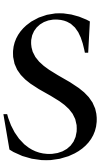

INCE the introduction of low molecular weight heparins, which are relative contraindications for the concomitant use of continuous postoperative epidural analgesia, continuous lumbar plexus blocks have been suggested as possible alternatives for analgesia after total knee replacement (TKR). ${ }^{1-5}$ Continuous lumbar plexus blocks decrease morphine consumption and may facilitate rehabilitation. ${ }^{1-4,6}$ Two main techniques can be used: the anterior three-in-one femoral nerve (FEM) block and the posterior lumbar plexus (psoas compartment, PSOAS) block. The latter may achieve a more complete blockade of the lumbar plexus since it provides more consistent blockade of the obturator nerve, one of the four nerves implicated in the sensory innervation of the knee. ${ }^{7}$

Despite the theoretical advantages of the PSOAS block, it is infrequently used. One possible reason may be the absence of pharmacokinetic data. To date, there are no data available on local anesthetic blood concentrations achieved after a continuous PSOAS block. Data are available for the three-in-one FEM block but extrapolation may be erroneous as the site of injection of a local anesthetic may affect its absorption and maximal blood concentration achieved $\left(\mathrm{C}_{\max }\right)$ and/or the timing of $\mathrm{C}_{\max } \cdot{ }^{8}$ Since the posterior approach results in injection of local anesthetic into or close to muscles, which are richly vascularized tissues, we hypothesized that the PSOAS block may lead to higher blood concentrations of local anesthetics than the three-in-one FEM block. The aim of this study is to compare plasma local anesthetic concentrations in patients undergoing a continuous PSOAS block to those in patients undergoing a continuous three-in-one FEM block.

\section{Methods}

The local Ethics Committee approved the study protocol and written informed consent was obtained from all patients. This study was a substudy of a randomized controlled trial that compared the clinical efficacy of $i v$ patient-controlled analgesia (PCA) with morphine, PCA plus continuous PSOAS block, and PCA plus continuous three-in-one FEM block in adult (20-80 yr of age), American Society of Anesthesiologists (ASA) physical status class I to III patients undergoing primary TKR for osteoarthritis. ${ }^{6}$ A convenience sample consisting of the first 24 patients to receive one of the two lumbar plexus blocks in that study were enrolled in this substudy. Patients were excluded if they were allergic to amide local anesthetics, fentanyl, or midazolam; had a history of hepatic or renal insufficiency (serum creatinine $>150$ $\mu \mathrm{mol} \cdot \mathrm{L}^{-1}$ ), alcohol or drug abuse, a contraindication to regional anesthesia, or anemia; or weighed over $110 \mathrm{~kg}$.
Catheters were inserted under sterile conditions after application of standard monitors (electrocardiogram, non-invasive blood pressure monitor, and pulse oximeter). Patients were sedated with $i v$ fentanyl 50 to $150 \mu \mathrm{g}$ and $i v$ midazolam $\mathrm{l}$ to $3 \mathrm{mg}$. Supplemental oxygen through nasal prongs was administered as required. The three-in-one FEM block was performed with an insulated $10.2 \mathrm{~cm}$ long, 18-gauge (G) Tuohy needle (CNB 400, Contiplex ${ }^{\circledR}$ B. Braun Medical Inc., Bethlehem, PA, USA) with the patient in supine position as described by Winnie et al. ${ }^{9}$ The PSOAS block was performed in the lateral decubitus position (operative side up) with an insulated $15.2 \mathrm{~cm}$ long, 18-G Tuohy needle (CNB 600, Contiplex ${ }^{\circledR}$ B. Braun Medical Inc., Bethlehem, PA, USA) with the technique described by Winnie et al. ${ }^{9}$ The catheter was inserted approximately $7 \mathrm{~cm}$ beyond the tip of the needle when contraction of the quadriceps (elevation of the patella) occurred with stimulation at $0.5 \mathrm{~mA}$ or less. All blocks were performed in a regional anesthesia induction room.

For all patients, a bolus of $30 \mathrm{~mL}$ of ropivacaine $0.5 \%$ plus epinephrine $1: 200,000$ was injected through the catheter. Three millilitres of the solution were injected as a test dose, followed by the rest of the solution if no evidence of local anesthetic toxicity occurred within three minutes of the test dose. An infusion of ropivacaine $0.2 \%$ was started immediately after the bolus at $12 \mathrm{~mL} \cdot \mathrm{hr}^{-1}$ for $48 \mathrm{hr}$. When the adequacy of the catheter position was confirmed by the appearance of sensory or motor blockade of the FEM, patients were transferred to the operating room. Spinal anesthesia with 12.5 to $15 \mathrm{mg}$ of isobaric bupivacaine $0.5 \%$ and fentanyl 10 to $15 \mu \mathrm{g}$ were administered for the surgery.

An $i v$ heparin lock was inserted for blood sampling in the upper limb contralateral to the iv infusion line. Blood samples of $6 \mathrm{~mL}$ were taken for the plasma ropivacaine levels before the injection, and at 15,30 , $45,60,75$, and $90 \mathrm{~min}$ and six, 24, and $48 \mathrm{hr}$ following the end of the bolus injection. Samples were placed on ice and centrifuged within one hour of collection. Plasma samples were stored at $-20^{\circ} \mathrm{C}$ until assay. For plasma ropivacaine concentration measurements, samples were prepared according to Björk et al. (precision of $10 \%$ ). ${ }^{10}$ To $1 \mathrm{~mL}$ of plasma sample, 5 $\mu \mathrm{g}$ of lidocaine was added as an internal standard, followed by the addition of $375 \mu \mathrm{L}$ of sodium carbonate $10 \%$ and extraction with $5 \mathrm{~mL}$ of $\mathrm{n}$-hexane:methylene chloride $(4: 1 \mathrm{v} / \mathrm{v})$ by gentle agitation for $30 \mathrm{~min}$. After centrifugation, the organic layers were transferred to other tubes and dried by evaporation. The residues were reconstituted with $250 \mathrm{~mL}$ of mobile 
phase $(70 \mathrm{mM}$ sodium sulfate in $1.25 \mathrm{mM}$ sulphuric acid: ACN 65:35 v/v) and analyzed using the high performance liquid chromatography (HPLC) separation technique reported by Arvidsson (precision of $10 \%)$ with some modifications. ${ }^{11}$ Aliquots of $100 \mu \mathrm{L}$ were injected into the analytical column (Hichrom S5 ODS 1 ) of the HPLC system at $40^{\circ} \mathrm{C}$ with ultraviolet detection at $210 \mathrm{~nm}$. The calibration curve for ropivacaine ranged from 125 to $4000 \mathrm{ng} \cdot \mathrm{mL}^{-1}$ of plasma.

Continuous data with a normal distribution were analyzed with unpaired t tests, two-way analysis of variance (ANOVA), or repeated measures of ANOVA, followed by the Scheffe's method if necessary. Ordinal data were analyzed with Mann-Whitney, Kruskall Wallis, or Friedman tests followed by StudentNewmann-Keuls analysis where appropriate. Nominal data were analyzed with Chi squared test or Fisher exact test. A $P$ value $<0.05$ was considered statistically significant.

\section{Results}

The two groups were comparable regarding age, weight, height, gender distribution, ASA physical status, length of surgery, central core temperature upon arrival at the recovery room, and total perioperative blood loss (Table I). Two patients (one from each group) were excluded from the data analysis because time zero samples were contaminated with lidocaine.

Patients in the PSOAS group had significantly higher plasma ropivacaine concentrations at 15, 30, and $60 \mathrm{~min}$ after the injection (ANOVA, $P<0.0001$; Table II). Maximal plasma concentrations were measured at $48 \mathrm{hr}$ after the injection for both groups. Apparent clearances and areas under the curve (AUC) were comparable between the two groups (Table II). One patient, weighing $83 \mathrm{~kg}$, in the FEM group achieved a plasma ropivicaine concentration of 6201 $\mathrm{ng} \cdot \mathrm{mL}^{-1}$ at $48 \mathrm{hr}$ after initiation of the continuous infusion. There was no correlation between plasma ropivicaine concentrations and body weight $\left(\mathrm{r}^{2}=\right.$ $0.085, P=0.21)$. No patient developed signs of local anesthetic toxicity.

\section{Discussion}

Early plasma ropivacaine concentrations were higher with the PSOAS block than with the three-in-one FEM block (Table II). These results reflect an earlier absorption of the local anesthetic in the psoas compartment and are consistent with anatomical observations that the lumbar plexus lies immediately behind or within the psoas muscle, a highly vascularized structure. ${ }^{12}$ To date, at least one case of acute local anesthetic toxicity has been described with the PSOAS block. ${ }^{13}$ However, this does not imply that the posterior technique increases the risk for toxicity when a continuous infusion is given through a correctly placed catheter, since blood concentrations achieved were equal in both groups after 24 $\mathrm{hr}$ of continuous infusion (Table II). Moreover, AUCs, which reflect the amount of circulating local anesthetic during the entire infusion period, were similar in the two groups (Table II).

The total plasma concentration of ropivacaine required to induce central nervous system toxicity is unknown. Muller et al. reported a patient who had grand mal seizures after the $i v$ injection of ropivacaine during an axillary brachial plexus block. ${ }^{14}$ Using a two-compartment model, they estimated that the maximal plasma concentration achieved in their

TABLE I Demographic data

\begin{tabular}{lll}
\hline & FEM $(n=11)$ & PSOAS $(n=11)$ \\
\hline Age $(\mathrm{yr})^{*}$ & $70.7 \pm 8.8$ & $67.5 \pm 8.2$ \\
Weight $(\mathrm{kg})^{*}$ & $81.8 \pm 8.8$ & $81.0 \pm 13.4$ \\
Height $(\mathrm{cm})^{*}$ & $162.1 \pm 10.4$ & $164.2 \pm 6.1$ \\
Gender $(\mathrm{F} / \mathrm{M})$ & $5 / 6$ & $7 / 4$ \\
ASA status $(\mathrm{I} / \mathrm{II} / \mathrm{III})$ & $1 / 10 / 0$ & $1 / 9 / 1$ \\
Length of the & & \\
surgery $(\mathrm{min})^{*}$ & $103.2 \pm 13.0$ & $106.6 \pm 18.2$ \\
$\begin{array}{l}\text { Body temperature in } \\
\text { recovery room }\left({ }^{\circ} \mathrm{C}\right)^{*}\end{array}$ & $35.7 \pm 0.8$ & $35.7 \pm 0.9$ \\
Total blood losses $(\mathrm{mL})^{*}$ & $817.3 \pm 413.1$ & $850.5 \pm 377.7$ \\
\hline
\end{tabular}

*Values are expressed as mean \pm standard deviation. ASA $=$ American Society of Anesthesiologists; FEM = group receiving continuous three-in-one femoral infusion; PSOAS = group receiving continuous posterior lumbar plexus (psoas compartment) infusion.

TABLE II Ropivacaine blood concentrations during continuous infusion

\begin{tabular}{lcl}
\hline & $F E M(n=11)$ & PSOAS $(n=11)$ \\
\hline Plasma concentrations $\left(n g \cdot m L^{-1}\right)^{*}$ & \\
$15 \mathrm{~min}$ & $465.8 \pm 420.3$ & $1,119.6 \pm 531.3 \dagger$ \\
$30 \mathrm{~min}$ & $547.3 \pm 422.6$ & $1,077.4 \pm 491.7 \ddagger$ \\
$45 \mathrm{~min}$ & $645.9 \pm 393.9$ & $1,039.9 \pm 416.7$ \\
$60 \mathrm{~min}$ & $679.1 \pm 407.2$ & $1,244.4 \pm 607.6 \S$ \\
$75 \mathrm{~min}$ & $755.7 \pm 481.6$ & $1,063.4 \pm 373.1$ \\
$90 \mathrm{~min}$ & $766.2 \pm 449.7$ & $1,032 \pm 339.1$ \\
Six hours & $1,074.4 \pm 500.2$ & $1,261 \pm 308.8$ \\
$24 \mathrm{hr}$ & $1,815.5 \pm 1034.3$ & $1,840 \pm 366.8$ \\
$48 \mathrm{hr}$ & $2,630.9 \pm 1470.3$ & $2,325.1 \pm 604.2$ \\
AUC $\left(\mathrm{mg} \cdot \mathrm{hr}^{-1} \cdot \mathrm{L}^{-1}\right)$ & $452.4 \pm 253.6$ & $433.4 \pm 99.0$ \\
\hline
\end{tabular}

${ }^{*} P<0.0001$, two-way analysis of variance for plasma concentrations between groups over $48 \mathrm{hr} ; \dagger P=0.0125 ; \ddagger P=0.039 ; \S P=$ 0.0357 . AUC $=$ area under the curve for $48 \mathrm{hr} ; \mathrm{FEM}=$ group receiving continuous femoral three-in-one infusion; PSOAS = group receiving continuous posterior lumbar plexus (psoas com partment) infusion. All values are expressed as mean \pm standard deviation. 
patient at the end of the injection was $5750 \mathrm{ng} \cdot \mathrm{mL}^{-1}$. Although the mean plasma concentrations measured in our study were well below that level, they tended to increase with time and a potentially toxic level was achieved in one of our patients at $48 \mathrm{hr}$ (6201 $\left.\mathrm{ng} \cdot \mathrm{mL}^{-1}\right)$ without any specific identifiable cause.

Burm et al. measured total and free plasma concentrations of ropivacaine obtained with epidural infusions after hip and knee replacements. ${ }^{15}$ With epidural infusions of 20 and $30 \mathrm{mg} \cdot \mathrm{hr}^{-1}$ for $72 \mathrm{hr}$, they also found that ropivacaine tended to accumulate with increasing plasma levels until the end of the infusion. Moreover, as in our study, they also observed wide interpatient variations in ropivacaine accumulation, metabolism, and excretion since one of their patients achieved a plasma concentration well above the rest of the cohort (7100 $\left.\mathrm{ng} \cdot \mathrm{mL}^{-1}\right)$, also without any identifiable precipitating factor. Neither Burm's patient nor our patient displayed any clinical signs of local anesthetic toxicity.

The elevation of $\alpha-1$ glycoprotein that is usually observed after major surgery may have modified the proportion of free ropivacaine and offered a certain degree of protection against local anesthetic toxicity. ${ }^{15}$ We did not measure free ropivicaine concentrations or plasma $\alpha-1$ glycoprotein concentrations. Nevertheless, our results suggest that long-term ropivacaine infusions should be used cautiously, especially in patients where amide local anesthetic metabolism may be decreased as in hepatic or cardiac insufficiency.

In our study, there was no correlation between ropivacaine concentrations and body weight. Other investigators have suggested that the maximal doses of local anesthetics in adults are more related to the site of injection than to body weight. ${ }^{16}$ Indeed, the $\mathrm{C}_{\max }$ observed in our study was not measured in the smallest patient.

In conclusion, with the PSOAS block, plasma ropivicaine concentrations increase earlier than with the threein-one FEM block, reflecting injection of a local anesthetic into a more vascularized area. However, when a continuous infusion is administered over $48 \mathrm{hr}$, both techniques are similar in their potential toxicity with comparable AUCs and maximal plasma concentrations. Finally, a continuous infusion of ropivacaine $0.2 \%$ at 12 $\mathrm{mL} \cdot \mathrm{hr}^{-1}\left(24 \mathrm{mg} \cdot \mathrm{hr}^{-1}\right)$ results in local anesthetic accumulation and may result in potentially dangerous blood concentrations if maintained at that rate for $48 \mathrm{hr}$.

\section{Acknowledgement}

The authors wish to thank Mrs. Lise Panneton, Respiratory Therapist, for her assistance in collecting the data.

\section{References}

1 Edwards ND, Wright EM. Continuous low-dose 3-in-1 nerve blockade for postoperative pain relief after total knee replacement. Anesth Analg 1992; 75: 265-7.

2 Singelyn FJ, Deyaert $M$, Joris D, Pendeville E, Gouverneur JM. Effects of intravenous patient-controlled analgesia with morphine, continuous epidural analgesia, and continuous three-in-one block on postoperative pain and knee rehabilitation after unilateral total knee arthroplasty. Anesth Analg 1998; 87: 88-92.

3 Capdevila X, Barthelet $\Upsilon$, Biboulet P, Ryckwaert $\Upsilon$, Rubenovitch J, d'Athis F. Effects of perioperative analgesic technique on the surgical outcome and duration of rehabilitation after major knee surgery.

Anesthesiology 1999; 91: 8-15.

4 Chelly JE, Greger J, Gebhard R, et al. Continuous femoral blocks improve recovery and outcome of patients undergoing total knee arthroplasty. J Arthroplasty 2001; 16: 436-45.

5 American Society of Regional Anesthesia and Pain Medicine. Regional anesthesia in the anticoagulated patient - defining the risks. 2002 [cited 17 May 2003]. Available from: URL: http://www.asra.com/ items_of_interest/consensus_statements/index.iphtml.

6 Kaloul I, Guay J, Côté C, Fallaha M. The posterior lumbar plexus (psoas compartment) block and the three-in-one femoral nerve block provide similar postoperative analgesia after total knee replacement. Can J Anesth 2004; 51: 45-51.

7 Parkinson SK, Mueller JB, Little WL, Bailey SL. Extent of blockade with various approaches to the lumbar plexus. Anesth Analg 1989; 68: 243-8.

8 Atanassoff PG, Weiss BM, Brull SJ. Lidocaine plasma levels following two techniques of obturator nerve block. J Clin Anesth 1996; 8: 535-9.

9 Winnie AP, Ramamurthy $S$, Durrani $Z$, Radonjic $R$. Plexus blocks for lower extremity surgery. New answers to old problems. Anesthesiology 1974; 1: 11-6.

10 Bjork $M$, Pettersson KJ, Osterlof G. Capillary gas chromatographic method for the simultaneous determination of local anaesthetics in plasma samples. J

Chromatogr 1990; 533: 229-34.

11 Arvidsson T, Eklund E. Determination of free concentration of ropivacaine and bupivacaine in blood plasma by ultrafiltration and coupled-column liquid chromatography. J Chromatogr B 1995; 668: 91-8.

12 Farny J, Drolet P, Girard M. Anatomy of the posterior approach to the lumbar plexus block. Can J Anaesth 1994; 41: 480-5.

13 Pham-Dang C, Beaumont SH, Floch H, Bodin J, Winer $A$, Pinaud $M$. Acute toxic accident following lumbar plexus block with bupivacaine (French). Ann Fr Anesth Réanim 2000; 19: 356-9. 
14 Muller M, Litz RJ, Hubler M, Albrecht DM. Grand mal convulsion and plasma concentrations after intravascular injection of ropivacaine for axillary brachial plexus blockade. Br J Anaesth 2001; 87: 784-7.

15 Burm AG, Stienstra R, Brouwer RP, Emanuelsson BM, van Kleef JW. Epidural infusion of ropivacaine for postoperative analgesia after major orthopedic surgery. Pharmacokinetic evaluation. Anesthesiology 2000; 93: 395-403.

16 Berde CB, Strichartz GR. Local anesthetics. In: Miller RD (Ed.). Anesthesia, 5th ed. Philadelphia: Churchill Livingstone Inc.; 2000: 491-521.

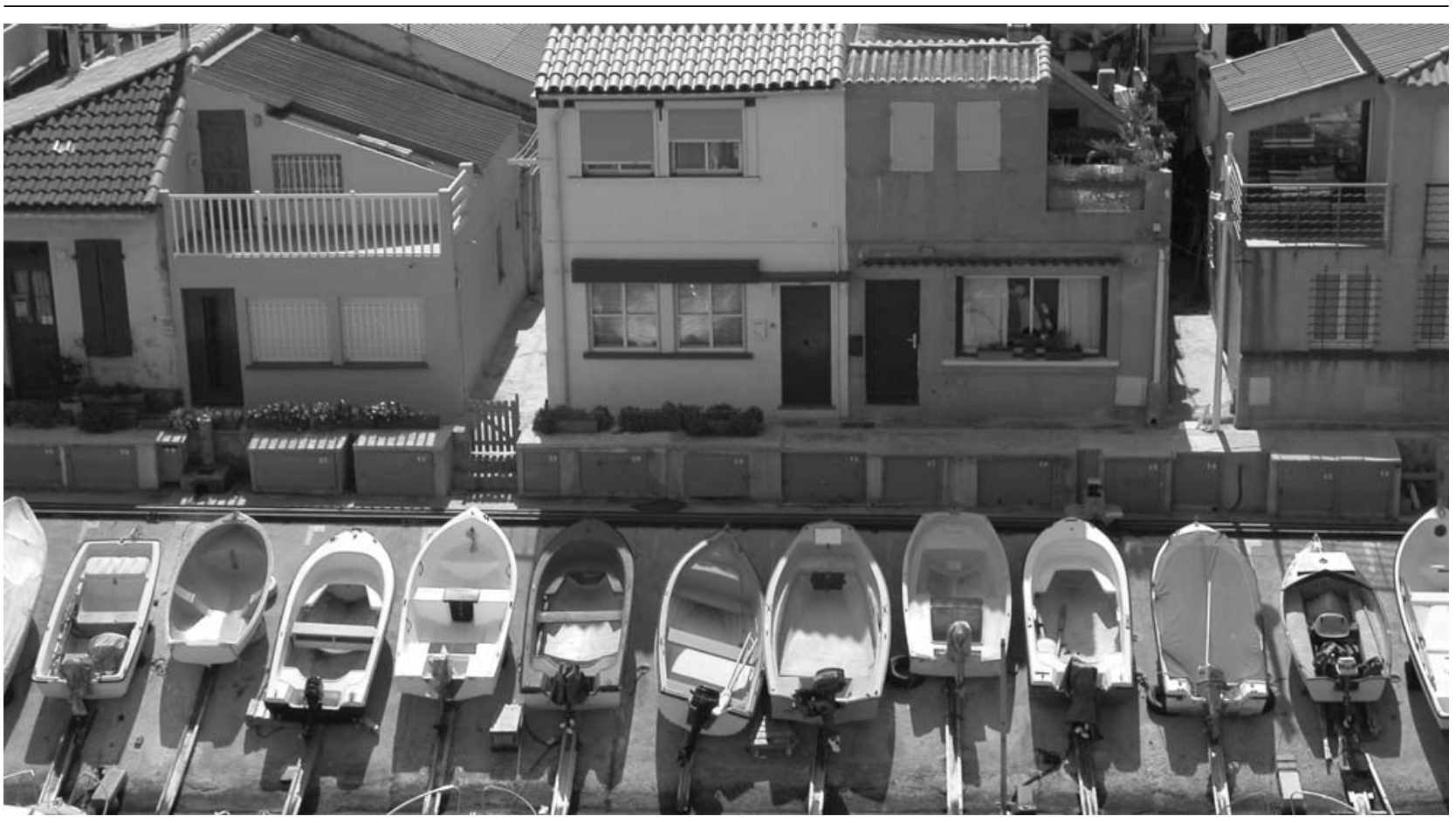

Barques au Vallon des Auffes 